UPPSALA UNIVERSITET

Working Paper 2006:1

Department of Economics

The Dynamics of Housing Allowance Claims in Sweden: A discrete-time hazard analysis

Jie Chen 
Department of Economics

Uppsala University

P.O. Box 513

SE-751 20 Uppsala

Sweden

Fax: +4618471 1478
Working paper 2006:1

Januari 2006

ISSN 0284-2904

\title{
The Dynamics of Housing Allowance Claims in Sweden: A discrete- TIME HAZARD ANALYSIS
}

\author{
JIE CHEN
}

Papers in the Working Paper Series are published on internet in PDF formats.

Download from http://www.nek.uu.se or from S-WoPEC http://swopec.hhs.se/uunewp/ 


\title{
The Dynamics of Housing Allowance Claims in Sweden: A discrete-time hazard analysis
}

January.04, 2006

\author{
Jie Chen ${ }^{12}$ \\ Department of Economics \& \\ The Institute for Housing and Urban Research (IBF), \\ Uppsala University
}

\begin{abstract}
This paper analyses the dynamics of the duration of housing allowance claims in Sweden during the period 1991 to 2002. The central concern in this paper is whether the Swedish housing allowance system creates dependence on welfare. Using longitudinal data from Swedish micro database-LINDA, this paper found that there is no evidence of negative duration dependence arising from the duration of housing allowance claims. This finding is consistent across different model specifications and various controls of the heterogeneity issue. Hence we come to the conclusion that a recipient's exit rate from the system does not decrease over the duration claim. This paper also shows that the demographic characteristics, educational background, labour market status and economic contextual conditions play important roles in determining recipients' conditional probability of exiting from the housing allowance system. However, there are substantial variations in the factors' impact across different household types.
\end{abstract}

JEL classification: H24, I38, R21

Keywords: housing allowance; discrete-time hazard; duration dependence

\footnotetext{
${ }^{1}$ Correspondence: Jie.Chen@ibf.uu.se, The Institute for Housing and Urban Research (IBF), Uppsala University, Telephone: 004625 4206539. Address: Box 785, Gävle, 80219, Sweden.

${ }^{2}$ The helpful comments from Mats Wilhelmsson, Viggo Nordvik and Geoffrey Meen are highly appreciated. The help from Mark Stephens on word editing is also gratefully acknowledged. But all remaining errors are my own. A slightly modified version of this article will appear at the incoming issue of European Journal of Housing Policy.
} 


\section{Introduction}

The past two decades have witnessed an increasing importance of housing allowances in the housing policies of most advanced countries (Fallis, 1993; Ditch et al., 2001; Kemp, 2000; Priemus \& Kemp, 2004). ${ }^{3}$ A growing number of research studies have been devoted to analysing the economic and social impacts of the housing allowance, e.g. its impacts on poor people's housing consumption (Kong \& Ridder, 1997; le Blanc \&Laferre, 2001), on rent levels in local housing markets (Susin, 2002; Laferrere \& le Blanc, 2004), the reduction of homelessness (Early, 2004), the recipients' labour supply (Fischer, 2000; Painter, 2001; Shroder, 2002), and the recipients tenure choice (Chen \& Öst, 2005). However, little is known about the dynamics of housing allowance claims themselves. In particular, there are two issues of fundamental importance but nevertheless are underexplored in the literature. First, what is the duration dependence pattern of housing allowance claims, or in other words how does the conditional exit propensity vary with a recipient's welfare history? ${ }^{4}$ Second, what are the key determinants of the duration of a recipient's housing allowance claim?

Knowledge of the dynamics of housing allowance claims is important to economic analysts and housing policymakers for several reasons: First, the funding of housing allowances is generally open-ended funding and driven by demand (Kemp, 2000), hence it is vital for governments to predict expenditure trends. Secondly, explicitly or implicitly, housing allowances are thought to help households only during economically difficult periods (Boverket, 1999; Stephens, 2005). Yet persistent participation in the housing allowance system may undermine the financing foundation of welfare. Thirdly, when the presence of long-term recipients is widespread, it may have very undesirable implications for society (Behrendt, 2000).

To see this, we need to distinguish two types of lengthy dependence on welfare (Plant, 1984). Some long-term recipients have persistent needs for public assistance because of their fundamental disadvantages in the labour market, e.g. the disabled and elderly. But some cases of prolonged

\footnotetext{
${ }^{3}$ Housing allowance is the term widely used in mainland Europe, but is better known as housing voucher and rent certificate in US, as housing benefit in UK, and as shelter assistance in Canada.

${ }^{4}$ Positive duration dependence implies a recipient's conditional exit propensity increases over their welfare history while negative duration dependence occurs when a recipient's leaving probability declines as his claim continues.
} 
dependence on welfare are asserted to be at least partly attributable to the "welfare trap". 5 The welfare trap hypothesis presumes a negative duration dependence pattern, i.e. a recipient's conditional leaving probability decreases as the length of claim extends. Considering that the housing allowance has become a key element in many social security systems, there is a growing concern on whether housing allowance yields the same welfare trap effect as other typical government transfers do (Fallis et al. 1995; Gibb, 1995; Stephens, 2005). Regarding the large-scale utilization and high generosity of housing allowances in Sweden, the welfare trap concern is particularly pertinent for this country.

On the other hand, there are several theoretical arguments suggesting that in-kind transfers generally produce less work disincentives than equivalent amount cash transfers do (Munro, 1989; Murray, 1980) and even could, at least in principle, induce more work efforts from assisted households (Leonesio, 1988; Schone, 1992). More importantly, regarding housing allowance's functions of assuring residential stability and widening neighborhood choice (Rosenbaum \& Harris, 2001; Newman \& Harkness, 2002), together with the long-held hypothesis that one's economic sufficiency ability could be improved via the said neighbourhood externalities (Turner, 1998; Katz et al., 2001; Ludwig et al., 2005), we could not exclude the possibility of a positive duration dependence pattern among the housing allowance spells. For lack of well-accepted theoretical grounds, as well as the substantial institutional variations across countries, it is not possible to determine a priori which type of duration dependence pattern exists within the housing allowance spells. This issue must be settled through empirical investigations in each country's specific context.

The research of housing allowance spell dynamics is still limited in the literature yet. Two rare exceptions are Hungerford (1996), who addressed the case of US housing assistance, and Nordvik \& Åhren (2005), who studied the Norwegian housing allowance system. Hungerford (1996) found exit rates were independent of length of receipt in the US housing assistance programme during the time frame he studied. Nordvik \& Åhren

\footnotetext{
${ }^{5}$ A primary argument of the so-called "welfare trap hypothesis" is the depreciation of human capital after periods of labour market inactivity (cf. Edin and Gustavsson, 2004). Another argument is that one's preferences might be shifted towards leisure and a "welfare culture" grows with the welfare experience (Plant,1984). Further, it is also suggested that one's welfare experience can be a negative signal of our personal motivation and competitiveness (Hoynes,2000). No matter what is its major source, the welfare trap hypothesis has been widely corroborated in various welfare systems of developed countries (Moffitt,1992; Behrendt, 2002)
} 
(2005) reached similar conclusions in the context of Norwegian housing allowance system.

This paper applies discrete-time hazard models to sample observations extracted from the Swedish micro-panel data-LINDA and the time period under study is 1991-2002. A major advantage of using panel data relative to a single stock data is its ability to decompose the true structural duration dependence from time trend effects. It also makes it easier to handle the effects of unobservable heterogeneity. Our sample is built on a registerbased database and thus the reliability is much greater than survey data.

The remaining sections of this paper are organized as follows: Section 2 introduces the institutional background of the Swedish housing allowance system; Section 3 develops the analytical framework and econometric techniques to be used in the empirical work; In Section 4, the data sources and characteristics of the sample observations are described; Section 5 presents the estimation results and discussions of the findings; and, finally, Section 6 ends the paper with the concluding remarks.

\section{The Swedish housing allowance system}

The housing allowance is now a central component of Swedish housing policy. In 2002, it was reported that about $60 \%$ of single parents and $15.3 \%$ of all Swedish households received some kind of housing allowance (cf. Table 1c) ${ }^{6}$. In the same year, the total housing allowance expenditure totalled 14.6 billion SEK and accounted for $0.61 \%$ of GDP, in contrast to the ratio of total housing production support which is only $0.08 \%$ and the ratio of tax deductions for mortgage interest, which is $0.46 \%$ ( $\mathrm{SCB}$, 2004;SCB, 2005). ${ }^{7}$ One should note that these scales were what remained after sharp declines in both types of expenditure and recipient numbers since the middle of the 1990s (Turner \& Whitehead, 2002). The historic evolution of the Swedish housing allowance system between 1991 and 2002 is demonstrated in Table 1a-b.

\footnotetext{
${ }^{6}$ The concept for "household" defined here is basis of the definition used for tax purposes: two adult persons that are married/cohabiting and have children in common belong to the same family. Cohabiting persons that have no children in common are regarded as separate households (Edin and Fredriksson, 2000).

${ }^{7}$ During 2004, the conversion rate of Euro vs. SEK is on average 1: 10.
} 
The Swedish National Board of Housing, Building and Planning (Boverkt) declares that the goal of the housing allowance is to "enable low-income households to live in good quality dwellings with adequate space" (MOS, 2004). It is emphasized that the housing allowance is designed to support households during economically difficult periods (Boverket, 1999). The Swedish housing allowance system is comprised of three separate schemes: 1) Housing allowances to families (bostadsbidrag, bostadstillägg till barnfamijer) granted to households with dependent children. Also available to childless households if all members of the household are aged less than 29 years; 2) Housing allowance supplements to elderly pensioners (bostadstillägg till pensionärer, BTP); 3) Housing allowance supplement to disabled pensioners (bostadstillägg till förtidspensionärer). These benefits are available to households of all tenures. This paper only discusses the housing allowance to families with children and does not consider the housing supplements to elderly or disabled pensioners, as the welfare trap is of minor relevance for these groups. This paper also disregards the young childless recipients as their exits are dominated by the 29 -year age limit. 
Table 1a: Expenditure on housing allowances in Sweden and its share of GDP, 1991-2002 (unit: Million SEK)

\begin{tabular}{lllll}
\hline Year & $\begin{array}{l}\text { Housing allowance } \\
\text { to Family }\end{array}$ & $\begin{array}{l}\text { Housing allowance to } \\
\text { Pensioners \& Disabled }\end{array}$ & $\begin{array}{l}\text { Total housing } \\
\text { allowance }\end{array}$ & $\begin{array}{l}\text { Percent of } \\
\text { housing } \\
\text { allowance in } \\
\text { GDP, \% }\end{array}$ \\
\hline 1991 & 5065 & 7702 & 12767 & .72 \\
1992 & 5928 & 8137 & 14065 & .80 \\
1993 & 7164 & 9750 & 16914 & .98 \\
1994 & 8669 & 10929 & 19598 & 1.09 \\
1995 & 9220 & 10440 & 19660 & 1.05 \\
1996 & 8373 & 9923 & 18296 & .97 \\
1997 & 6195 & 9544 & 15739 & .81 \\
1998 & 5749 & 9591 & 15340 & .76 \\
1999 & 4936 & 9970 & 14906 & .71 \\
2000 & 4283 & 9641 & 13924 & .63 \\
2001 & 4069 & 10420 & 14489 & .65 \\
2002 & 3892 & 10514 & 14406 & .64 \\
\hline
\end{tabular}

Source: First three columns from Table 6.2.5 in Yearbook of Housing and Building Statistics 2004 (Bostads- och byggnadsstatistisk årsbok 2004)

Table 1b: The total number of housing allowance recipients in Sweden, 1991-2002 (unit: 1000 households)

\begin{tabular}{lllll}
\hline Year & $\begin{array}{l}\text { Households } \\
\text { with children }\end{array}$ & $\begin{array}{l}\text { Childless } \\
\text { households }\end{array}$ & Pensioners & Total \\
\hline 1991 & 285 & 43 & 559 & 887 \\
1992 & 306 & 61 & 549 & 916 \\
1993 & 346 & 95 & 593 & 1034 \\
1994 & 406 & 132 & 608 & 1146 \\
1995 & 428 & 148 & 563 & 1139 \\
1996 & 403 & 68 & 538 & 1009 \\
1997 & 309 & 56 & 503 & 868 \\
1998 & 283 & 55 & 490 & 828 \\
1999 & 255 & 49 & 474 & 778 \\
2000 & 227 & 41 & 458 & 726 \\
2001 & 204 & 34 & 456 & 694 \\
2002 & 191 & 33 & 455 & 524 \\
\hline Source: Table 6.2.4 in Yearbook of Housing and Building Statistics 2004 (Bostads- och \\
byggnadsstatistisk årsbok 2004)
\end{tabular}

byggnadsstatistisk årsbok 2004) 


\section{Housing allowance schedule}

In Sweden, housing allowance to families is not an entitlement but a meanstested welfare benefit that eligible households must apply for. The available housing allowance is calculated using a two-step computation. In the first step, an applicable amount of allowance is calculated according to the applicant's household structure, number of children and amount of approved housing expenses. In the second step, the available amount of allowance is tapered from this amount according to how much the applicant's assessed income exceeds a specified threshold level. The income base $\mathrm{Y}$ is the applicant's own assessment of gross earnings over the forthcoming year plus $15 \%$ of the wealth exceeding a threshold level. ${ }^{8}$ The taper rate for families with children is $20 \%$. Concerning eligible housing expenses, for renters this is the rent payment plus heating and other charges directly related to the dwelling, and for homeowners and tenant-owners it is the mortgage payment plus the real-estate tax and $70 \%$ of any site-lease rent if any, as well as heating and other operating accommodation expenses, according to a standard deduction.

Defining $H A_{p}$ as the applicable housing allowance and $H A^{*}$ as the available housing allowance, the following schedule apply:

(1) $\mathrm{HA}_{\mathrm{p}}=\mathrm{CHA}+\mathrm{RHA}$

(2) $\mathrm{HA}^{*}=\mathrm{HA}_{\mathrm{p}}$ if $\mathrm{Y}<\mathrm{Q}$

$$
=\max \left[0, \mathrm{HA}_{\mathrm{p}}-0.2^{*}(\mathrm{Y}-\mathrm{Q})\right] \text { if } \mathrm{Y}>=\mathrm{Q}
$$

In Equation 1, CHA is the needs-tested subsidy, the part of $H A_{p}$ related to number of children; RHA is the "pure" housing allowance, the part of $H A_{p}$ related to housing expenses. In Equation 2, $Y$ is assessed total income and $Q$ is income threshold level. Since 1997, available housing allowance is computed initially according to the applicant's own estimated income but is adjusted retrospectively when that year's income tax is completed. If the recipient has previously received too much allowance, he is obliged to

\footnotetext{
${ }^{8}$ The gross earning is what the Swedish Tax Authority defined as "the sum of all income from employment, business and capital" (summa förvärvs-och kapitalinkoms), where the unemployment insurance is also taken into account. But government transfers like social assistance (socialbidrag) and child allowance (barnbidrag) are exempted. In practice, 15 percent of the wealth surpassing a threshold level is included in the calculation of assessed income. In 2004, the threshold level of wealth is 100,000 SEK.
} 
repay the difference plus an administration fee. If it turns out that the recipient should have received more, he can be compensated with interest. ${ }^{9}$

The levels of $C H A, R H A, Y$ and $Q$ vary according to family structure. Details are illustrated in Tables $2 \mathrm{a}-\mathrm{b}$.

The adjustments on the levels of child allowance and approval thresholds for housing expenditures are fairly small and are almost zero after 1996. In contrast, the threshold level of annual assessed income $Q$ is changed periodically to account for the effect of inflation. For example, in 19921993 its level was 91,000 SEK and was raised to 110,000 SEK in 1994 and was further increased to 115,000 SEK in 1995. But since 1996 it has been fixed at 117,000 SEK per household if the applicant is single and 58,500 SEK per applicant if the applicant is married. More details of the regulations governing the Swedish housing allowance system can be found in Appendix 4 of Boverket (1999).

Using schedules like those outlined in Tables $2 a-b$, we can infer the maximum applicable housing allowance for each household type in any given year. Based on Eq.2, the income ceiling level above which a household ceases to be eligible for housing allowance can always be deduced using the following equation, $I^{*}=5^{*} H A_{p}+Q$. The income ceiling refers to the applicant's own assessed income if the applicant is single and to the total joint income of the couple if the applicant is married. Columns 2 and 4-5 of Table 2c report these calculations. Column 6 of Table 2c suggests that even households with annual incomes as high as 345,000 SEK per year were among the recipients of housing allowance in 1996.

It should be noted that in 1996 the top $10 \%$, median, and bottom $10 \%$ levels of annual work income for a full-time employed Swedish female worker were 283,900, 198,100 and 147,400 SEK, respectively. For male full-time workers, these three figures were 397,900, 236,700, and 169,600 SEK, respectively (SCB, 2005). This means that a single mother with two children could expect to receive a housing allowance of around 1,800 $\mathrm{SEK} /$ month even if she held an average-pay full-time job at the same time. More surprisingly, even couples in which both parties held full-time jobs could also expect to receive housing allowance.

\footnotetext{
${ }^{9}$ See more details from http://www.forsakringskassan.se/privatpers/bostadsbidrag/ on the website of Swedish Social Insurance Agency. 
Table 2a: Swedish Housing allowance schedule in 1996

\begin{tabular}{|c|c|c|c|c|}
\hline $\begin{array}{l}\text { Number } \\
\text { children }\end{array}$ & $\begin{array}{l}\text { of Child grant } \\
\text { [SEK/month] }\end{array}$ & $\begin{array}{l}75 \% \text { of housing } \\
\text { expenditures } \\
\text { between } \\
\text { [SEK/month] }\end{array}$ & $\begin{array}{l}50 \% \text { of housing } \\
\text { expenditures } \\
\text { between } \\
{[\mathrm{SEK} / \text { month }]}\end{array}$ & $\begin{array}{l}\text { Income threshold } \\
\text { [SEK/year] }\end{array}$ \\
\hline 1 child & 600 & $2000-3000$ & $3000-5300$ & 117,000 \\
\hline 2 children & 900 & $2000-3300$ & $3300-5900$ & 117,000 \\
\hline $3+$ children & 1200 & $2000-3600$ & $3600-6600$ & 117,000 \\
\hline
\end{tabular}

Table 2b: Swedish Housing allowance schedule in 1997

\begin{tabular}{|c|c|c|c|c|c|c|}
\hline $\begin{array}{l}\text { Number of } \\
\text { children }\end{array}$ & $\begin{array}{l}\text { Child grant } \\
\text { [SEK/Mth] }\end{array}$ & $\begin{array}{l}75 \% \text { of } \\
\text { housing } \\
\text { expenses } \\
\text { between } \\
\text { [SEK/Mth] }\end{array}$ & $\begin{array}{l}50 \% \text { of } \\
\text { housing } \\
\text { expenses } \\
\text { between } \\
\text { [SEK/Mth] }\end{array}$ & $\begin{array}{l}\text { Maximum } \\
\text { living area } \\
\text { [square } \\
\text { metres] }\end{array}$ & $\begin{array}{l}\text { Income } \\
\text { threshold } \\
\text {-single } \\
\text { [SEK/year] }\end{array}$ & $\begin{array}{l}\text { Income } \\
\text { threshold } \\
\text {-couple } \\
\text { [SEK/year] }\end{array}$ \\
\hline 1 child & 600 & $2000-3000$ & $3000-5300$ & 80 & 117,000 & $\begin{array}{l}58,500 / \\
\text { applicant }\end{array}$ \\
\hline 2 children & 900 & $2000-3300$ & $3300-5900$ & 100 & 117,000 & $\begin{array}{l}58,500 / \\
\text { applicant }\end{array}$ \\
\hline 3 children & 1200 & $2000-3600$ & $3600-6600$ & $120-160$ & 117,000 & $\begin{array}{l}58,500 / \\
\text { applicant }\end{array}$ \\
\hline 4 children & 1500 & $2000-3600$ & $3600-6600$ & $120-160$ & 117,000 & $\begin{array}{l}58,500 / \\
\text { applicant }\end{array}$ \\
\hline $5+$ children & 1800 & $2000-3600$ & $3600-6600$ & $120-160$ & 117,000 & $\begin{array}{l}58,500 / \\
\text { applicant }\end{array}$ \\
\hline
\end{tabular}

Source: Boverket (1999).

Note: After 1998, the children grant was again simplified to three classes: 1, 2, and 3+.

Table 2c: The maximum applicable housing allowance and the income ceiling of eligibility in 1996

\begin{tabular}{|c|c|c|c|c|c|}
\hline $\begin{array}{l}\text { Number of } \\
\text { children }\end{array}$ & $\begin{array}{l}\text { Maximum } \\
\text { applicable } \\
\text { housing } \\
\text { allowance } \\
\text { (SEK/Mth) }\end{array}$ & $\begin{array}{l}\text { Maximum } \\
\text { housing } \\
\text { allowance } \\
\text { utilized by } \\
\text { recipients } \\
\text { (SEK/Mth) }\end{array}$ & $\begin{array}{l}\text { Maximum } \\
\text { applicable } \\
\text { housing } \\
\text { allowance } \\
\text { (SEK/year) }\end{array}$ & $\begin{array}{l}\text { Income } \\
\text { ceiling of } \\
\text { eligibility } \\
\text { (SEK/year) }\end{array}$ & $\begin{array}{l}\text { Maximum } \\
\text { income of } \\
\text { recipient } \\
\text { recorded } \\
\text { (SEK/year) }\end{array}$ \\
\hline 1 child & 2,500 & 2,500 & 30,000 & 267,000 & 261,000 \\
\hline 2 children & 3,175 & 3,175 & 38,100 & 307,500 & 301,000 \\
\hline $3+$ children & 3,900 & 3,900 & 46,800 & 351,000 & 345,000 \\
\hline
\end{tabular}

Note: Columns 3 and 6 are based on Appendix Table 4 of Boverket (1999). 
Thus, although nearly all full-time workers are subject to income deduction when applying for housing allowance, we can see that the income threshold level is actually set fairly high. Compared to other countries (Kemp, 2000; Âhren, 2004; Stephens, 2005), it is apparent that the Swedish government operates a generous housing allowance system. Its generosity interacting with other parts of the Swedish welfare system that is already internationally renowned for its generosity, inevitably invites one to speculate regarding the extent to which the housing allowance may weaken a household's work incentives. Is there a welfare trap within the Swedish housing allowance system? This concern provides the primary purpose of this paper.

\section{Distribution and impacts of housing allowance in Sweden}

Below we elaborate on the distribution of housing allowance recipients across different household types and its impact on improving housing affordability for each of them. This is illustrated using information from 2002. Although the year 2002 may not seem an ideal point in time for examining the impacts of housing allowance in Sweden as the recipient number was at a historical low (cf. Table 1b), it nonetheless highlights that the importance of housing allowance to low income households even when the national economy is performing well. 
Table 3: Distribution and impacts of housing allowance by household type in 2002

\begin{tabular}{|c|c|c|c|c|c|c|}
\hline $\begin{array}{l}\text { Household } \\
\text { types }\end{array}$ & $\begin{array}{l}\text { Recipient } \\
(1000)\end{array}$ & $\begin{array}{l}\text { Share in } \\
\text { group } \\
\text { population } \\
(\%)\end{array}$ & $\begin{array}{l}\text { Share in } \\
\text { total } \\
\text { recipients } \\
(\%)\end{array}$ & $\begin{array}{l}\text { Relative } \\
\text { Consumpti } \\
\text { on ratio }{ }^{1} \\
(\%)\end{array}$ & $\begin{array}{l}\text { Annual } \\
\text { Allowance } \\
\text { per } \\
\text { household } \\
\text { (SEK) } \\
\end{array}$ & $\begin{array}{l}\text { Coverage } \\
\text { ratio }^{2}(\%)\end{array}$ \\
\hline $\begin{array}{l}\text { One-person } \\
\text { household } \\
\text { aged } 65-\end{array}$ & 98 & 12.31 & 18.70 & 57.05 & 20300 & 47.21 \\
\hline $\begin{array}{l}\text { One-person } \\
\text { household } \\
\text { aged } 65+\end{array}$ & 245 & 41.39 & 46.76 & 71.66 & 21500 & 49.20 \\
\hline $\begin{array}{l}\text { Childless } \\
\text { couples } \\
\text { aged } 65-\end{array}$ & 8 & 1.32 & 1.52 & 49.71 & 12500 & 28.60 \\
\hline $\begin{array}{l}\text { Childless } \\
\text { couples } \\
\text { aged } 65+\end{array}$ & 20 & 5.25 & 3.82 & 52.54 & 20300 & 39.42 \\
\hline $\begin{array}{l}\text { Singles with } \\
\text { children }\end{array}$ & 79 & 59.40 & 15.08 & 85.51 & 21300 & 34.52 \\
\hline $\begin{array}{l}\text { Couples } \\
\text { with } \\
\text { children }\end{array}$ & 32 & 5.55 & 5.92 & 54.34 & 16900 & 25.26 \\
\hline $\begin{array}{c}\text { Couples } \\
\text { with } 1 \text { child }\end{array}$ & 7 & 4.19 & 1.34 & 72.31 & 16000 & 23.43 \\
\hline $\begin{array}{c}\text { Couples } \\
\text { with } 2 \\
\text { children }\end{array}$ & 9 & 3.31 & 1.72 & 57.30 & 17500 & 26.28 \\
\hline $\begin{array}{l}\text { Couples } \\
\text { with } 3+ \\
\text { children }\end{array}$ & 15 & 12.50 & 2.86 & 55.82 & 16900 & 25.28 \\
\hline Others & 43 & 11.91 & 8.21 & 57.80 & 24500 & 39.33 \\
\hline All & 524 & 15.29 & 100 & 51.47 & 21000 & 42.25 \\
\hline
\end{tabular}

Source: Author's own calculation based on Table 19.d of Surveys of Housing and Rents 2002 (Bostads- och hyresundersökningen 2002, SCB 2002)

Note: 1.Relative consumption ratio $=$ recipient's mean consumption expenditure/all household's mean consumption expenditure in this group; 2. Coverage ratio=housing allowance/gross housing expenditures; 3 . Housing allowance here includes the benefits to the disabled and pensioners. 
Table 3 includes the housing allowances paid to elderly and disabled pensioners. Overall in 2000, $15.3 \%$ of Swedish households received housing allowance and the average annual benefit per recipient household received was $21,000 \mathrm{SEK}$, which covered $42.25 \%$ of the recipients' housing expenses. Excluding the single and couple groups aged above 65 years, the remaining groups correspond roughly to the recipients of housing allowance to families. Among these recipients, we can see that the singles with children group constitutes the largest portion. This is also the household group that with the highest claimant percentage: almost $60 \%$ of single parents were assisted. It should be noted, however, that although only $5.5 \%$ of the couple with children households received housing allowance, these recipients were more economically disadvantaged than others. The mean consumption expenditure per consumer unit of this recipient group was only 57,600 SEK in 2002 , only $54.34 \%$ of that of all couple with children recipients. This number was lower than that of single parent recipients, which was 59,000 SEK. But the couple with children recipients received less assistances compared to the single parent recipients. The average allowance that the couple with children recipient households received was 16,900 SEK and covered $25.26 \%$ of their housing expenses. In contrast, single parent recipients received on average 21,300 SEK in benefits, which covered $34.52 \%$ of their housing expenses. From Table 3, the functional importance of housing allowance in supporting poor Swedish households' housing consumptions is evident.

\section{The 1997 reform}

The Swedish housing allowance system experienced a series of radical reforms during 1996-1997 (Boverket, 1999). The most noticeable change in this series of reform is that childless households with household head aged above 29 years are no longer eligible for the housing allowance. As Tables 2a-b demonstrate, the 1997 reform also affected the couple with children households markedly. However, for the purpose of exploring the welfare trap it is not necessary to explore these reforms further. However, the details and implications of the 1997 reform are discussed in an accompanying paper, Chen (2005). 


\section{Analytical Framework and Methodology}

An initial word regarding the empirical strategy is that there is no need to consider the competing-risk framework in this paper. ${ }^{10}$ The data we use are constructed to ensure that the exit is not due to qualification reason, e.g. dependent children's leaves from parent's home. It is also ensured that the exit path could not be the housing allowance to the elderly or disabled pensioners. One should also note that the exit path from the housing allowance system could not be social assistance in Sweden. This is because social assistance benefits in Sweden are available only after the applicants exhaust all other welfare programs, including housing allowance.

\section{Econometric models}

In the econometric analysis, the conditional probability of one event happening is usually termed as hazard:

(1) $\operatorname{pr}\left(E_{i, t}=1 \mid t \leq T<t+1\right)=\lambda_{i}(t)$

Following the survival analysis literature, we formulate the exit hazard of recipient $i$ at time period $t$ as a function of both duration-time variable and explanatory variables with unknown parameter vector $\Theta$.

(2) $\lambda_{i}(t)=\lambda_{i}\left(t, X_{i t}, \varepsilon_{i} ; \Theta\right)$

The covariate vector $X$ includes both time-constant and time-varying observable explanatory variables, but for simplicity we only use the notion $X_{i t}$. The term $\varepsilon_{\mathrm{i}}$ refers to the time-invariant unobservable individual heterogeneity. The duration time variable $t$ enters the model to capture the relationship between the exit hazards and welfare history.

\section{The survival analysis of the duration of claims}

Since the length of a claim is an outcome of sequential choices, we get the unconditional probability that the spell length is exactly $t$ periods as:

\footnotetext{
${ }^{10}$ The competing-risk model implies several exiting paths to be considered simultaneously.
} 
(3) $\operatorname{Pr}\left(T_{i}=t\right)=\lambda_{i}(t) \prod_{k=1}^{t-1}\left(1-\lambda_{i}(t)\right)$

The unconditional probability that the spell length is more than $t$ periods is:

(4) $\operatorname{Pr}\left(T_{i}>t\right)=S_{i}(t)=\prod_{k=1}^{t}\left(1-\lambda_{i}(k)\right)$

Therefore once the hazard function is specified, the expected spell duration can be characterized straightforwardly. Ignoring the censoring issue temporarily, we have the likelihood for the $N$-observation grouped survival data as follows (Lancaster, 1979):

(5)

$$
\begin{aligned}
L & =\prod_{i=1}^{N}\left[\operatorname{Pr}\left(T_{i}=t\right)\right]^{E_{i, j}}\left[\operatorname{Pr}\left(T_{i}>t\right]^{1-E_{i, j}}\right. \\
& =\prod_{i=1}^{N}\left[\lambda_{i}(t) \prod_{k=1}^{t-1}\left(1-\lambda_{i}(t)\right]^{E_{i, t}}\left[\prod_{k=1}^{t}\left(1-\lambda_{i}(k)\right)\right]^{1-E_{i, t}}\right. \\
& =\prod_{i=1}^{N}\left[\left(\frac{\lambda_{i}(t)}{1-\lambda_{i}(t)}\right)^{E_{i, t}} \prod_{k=1}^{t}\left(1-\lambda_{i}(k)\right], \mathrm{i}=1,2, \ldots, \mathrm{N}\right.
\end{aligned}
$$

and its $\log$ form:

(6) $\log L=\sum_{i=1}^{N} \sum_{k=1}^{t}\left[E_{i, k} \log \lambda_{i}(t)+\left(1-\lambda_{i, k}\right) \log \left(1-\lambda_{i}(k)\right)\right]$

The term $E_{i, t}$ is the indicator of exiting as previously defined.

It now becomes clear that the likelihood of grouped survival data is exactly the same as a binary-response regression with $\mathrm{E}_{\mathrm{i}, \mathrm{t}}$ as the dependent variable. Thus, the discrete-time hazard models can be applied with any standard binary-response GLM (Generalized Linear Method). The most popular options are the logit models that credited to Cox (1972) and the complementary log-log models developed by Prentice \& Gloeckler (1978). The logit model consumes shorter computation time, but the complementary log-log model has the advantage that the coefficient estimates are invariant to the length of time intervals. In most cases, the two models produce similar results. 


\section{Duration dependence}

The fundamental motivation of this paper is to determine whether the Swedish housing allowance system might generate welfare traps. In econometric terms, the testing of the welfare trap hypothesis is undertaken through the identification of duration dependence pattern, which is just the relationship between the past histories of welfare receipt to the current propensity of exiting. To obtain a genuine duration dependence pattern that distinguishing from "spurious duration dependence", we need to control cautiously for both the impacts of observable individual characteristics and the effects of unobservable individual heterogeneity.

Meyer (1990) proposed a proportional hazard specification to estimate flexibly the baseline hazard:

(7) $\lambda_{i}\left(t, X_{i} ; \theta\right)=\phi\left(X_{i, t}^{\prime} \beta\right) \sum_{j=1}^{J} \lambda_{0}(j) * D(j)$

In this proportional hazard specification, the shape of the baseline hazard function is common to all samples and the effect of covariates is to shift the individual observation's hazard location vertically and proportionately without affecting the baseline hazard shape. Meyer (1990) pointed out that the semi-parametric approach loses only minimal efficiency compared to the parametric approach, but the consistency of parameters is ensured through flexible non-parametric estimation of baseline hazard.

\section{Frailty}

The observed pattern of the relationship between exit rates and claim duration can be highly spurious if we do not control well for the influences of unobservable individual heterogeneity. For example, the observed declines in the aggregate exit rates can be due merely to people with high exit propensity (but unmeasured) having already left in the earlier periods leaving only people with low exit propensity (unmeasured too) behind in the system. But this does not necessarily suggest those remained behind have declining exit rates. From a policy point of view, it is highly relevant to disentangle true from spurious duration dependence.

In the literature, it is commonly assumed that a household's unobservable individual heterogeneity in the propensity to end an event is time-invariant. 
Unobservable heterogeneity in duration data is often termed as frailty. It can be viewed as a summary of omitted variable effects.

Following Prentice \& Gloeckler (1978) and Meyer (1990), a PrenticGloeckler-Meyer (PGM) type semi-parametric complementary log-log discrete-time hazard model is the primary model used in this paper:$$
\lambda\left(t, X_{i t} ; \lambda_{0}(t), \beta\right)=1-\exp \left(-\exp \left(\sum_{j=1}^{J} \lambda_{0}(j) * D(j)+X_{i t}^{\prime} \beta+\log \left(\varepsilon_{i}\right)\right)\right.
$$

The term $\varepsilon_{\mathrm{I}}$ is the frailty term---the summary term of time-invariant unobservable individual heterogeneity.

It is popular to specify the frailty term with Gamma distribution (Meyer, 1990) or normal distribution (Bhat, 1996). Note that the model estimated with a normally distributed frailty term on panel data is exactly a random effect panel data model. Heckman \& Singer (1984) proposed a nonparametric specification of the frailty term with mass-point discrete distribution. The econometrics literature has suggested that, if we have specified a fully flexible specification of baseline hazard, the choice of frailty distribution should be of minor importance and the covariate parameters are little affected by distribution specification of frailty term (Han \& Hausman, 1990; Meyer, 1990). In the empirical analysis, we experimented with all three specifications for frailty distribution.

\section{Censoring}

The censoring problem in duration data appears when we are unable to observe the claim throughout its duration, where the right censoring indicates the exit time of the spell is not observed and the left censoring implies that we have no information on when the claim begins. The right censoring of spells has been routinely handled in most statistical software with the assumption that the censoring is independent of the duration distribution, conditional on the covariates $X$. But the treatment of left censoring is much more problematic as it is a very complex issue. We are not able, in general, to get the information on the entry rate into the initial date. In the literature, there is no widely accepted strategy concerning this issue yet (Singer \& Willett, 2003). Most studies proceed by imposing very restrictive assumptions or discarding all left-censored observations. This paper chooses to throw out all left-censored spells in the empirical analysis, as its share is fairly small among the total spell samples (less than 17\%). We have, however, run the estimation with the inclusion of left-censored 
observations and found that the results are nearly not affected. This can be attributed partly to the fairly stable hazards after the first year in our sample (cf. estimation result section).

\section{Data and Sample Description}

\section{Data sources}

The empirical analysis uses data from LINDA, the Swedish longitudinal individual database, which is a $3 \%$ annual representative sample of the entire Swedish population that has been followed since 1960. It is also complemented every five years with national survey data. As it is taxregister based, the quality and reliability of data is exceptionally good (Edin \& Fredriksson, 2000). The data used in this paper is extracted from LINDA family panel data spanning from 1991 to 2002.

The county-level local unemployment rate, which is defined as the proportion of the registered unemployed and labour market program participants to the entire labour force population, is obtained from SCB (2005). The county-level local single family housing sale price level is aimed to proxy the local housing market conditions and is provided by the Institute for Housing and Urban Research (IBF) at Uppsala University.

\section{Sample construction}

Based on LINDA, a household is defined as a recipient if the received at least one year's housing allowance (bostadstillägg till barnfamijer) during the period under study. Only observations that were not disabled or under 65 years of age at the exit year are included in the sample. This is to ensure that they did not exit to elderly or disabled pensioner housing allowance, thus alleviating the complication of multiple exit-path problems. We also restrict the samples to recipients who had at least one child under age 16 at exit year to guarantee that their exits were not due to the loss of eligibility. Finally, all full-time students have been disregarded.

After imposing these selection criteria, we recorded 74,140 recipient observations from LINDA panel data 1991-2002. Recipients who were on welfare in 1991 are tracked back to 1990 to identify their entry time. If 
spells were already ongoing in 1990 or if the entry time was missing due to panel attrition, they are regarded as left-censored spells. For reasons mentioned previously, all left-censored spells have been omitted from the samples. The size of remaining recipient observations is 57,601. The mean length of claim for these recipient sample observations is 3.78 years and the standard variance is 2.42 years. We should point out that recipient observations with multiple spells are recorded only (the longest spell is recorded). The share of multi-spell recipient observations is $16 \%$. If we record the first spell rather than the longest one, there is no major change in the findings whatsoever.

Unfortunately, applying discrete time frailty models is hideously computer intensive and consumes enormous computation time. Limited by our computation resources, we can only use a $20 \%$ random sample of the remaining recipient data in the empirical analysis: the recipient observation number of this sample is 11,515. To examine the household type differentials, the recipient samples are split into the single parent recipient sub-sample and the couple with children recipient sub-sample according to their household structure status upon entry time. The literature commonly suggests that females and males have systematically different responses to welfare benefits (Moffitt, 2000), thus we further stratify the single parent recipient sample into the single mother and single father recipient groups. All together, the remaining samples are comprised of 2,974 single mother recipients, 2,131 single father recipients, and 5,790 couple with children recipients (among which 2,183 are husband-headed and 3,597 are wifeheaded). The distribution of sample spells by observation year and by duration is given in Table A.1, presented in the Appendix. Examining the upper section of Table A.1, we can see that most recipients stayed briefly: $41 \%$ exited within 2 years, $67 \%$ exited within 4 years, and only $4 \%$ remained after 9 years. The mean length of all uncensored spells is 3.78 years (S.E. $=2.42)$, with noticeable differentials across household types. The year distribution of sample spells is in line with the aggregate historical pattern of the Swedish housing allowance system reflected in Table 1b, which peaked in 1996 and fell heavily afterwards.

However, in LINDA, subject to the institutional feature of Swedish household registration system, the "household head" in the couples, only indicates who the older person within this couple is and has nothing to do with who "makes the decisions". We should point out that there is no evidence that the husband-headed couple (the husband-older couple) recipients are structurally different from the wife-headed couple (the wife- 
older couple) recipients regarding spell duration. ${ }^{11}$ However, to ensure that we are actually comparing the behaviour responses expressed by the household decision-makers, we use the husband-headed (husband-older) couple samples to stand for all couple samples.

The summary statistics of sample recipients used in the regression are reported in Table A.2 contained in the Appendix. Examining Table A.2, we find that, overall, the recipients were concentrated primarily at the age interval of 25-45, most did not have an education higher than high school, and quite a large proportion were either unemployed or receiving social assistance at entry time.

\section{Time of variables measured}

In estimating the effects of individual characteristics on hazards, using the values measured upon entry time or using the current values deserves careful consideration. Although the panel nature of our data allows for the use of the current values of household characteristics, we nevertheless chose only to use those measured at entry time. One argument for this is that we are interested in how to use a recipient's information at entry time to predict when she/he will leave. But, more importantly, we want to avoid possible endogeneity issues between changes in a recipient's household characteristics and his/her exit hazards. A recipient who has developed a strong dependence on welfare after entering the system could increase his/her probability of remaining in the system by, for example, rejecting low-paid jobs or having low incentives to obtain more education. We therefore feel it is difficult to draw conclusions regarding causality relationships when using time-varying household characteristics. Nonetheless, we have entered for local housing/labour market variables in the model as time-varying variables, since these changes were exogenous.

\section{Estimation Results and Discussion}

To begin with, we estimated the hazards for the single mother recipients, the single father recipients and the couple with children recipients, respectively. This approach aims to minimize the disturbances of group-

\footnotetext{
${ }^{11}$ The LR test statistic of homogeneity between the two couple groups with respect to the distribution of spell duration is 3.58 and not significant at $5 \%$.
} 
specific heterogeneity and examine how the duration dependence patterns and covariate effects vary across different household types.

\section{Model estimation results}

In our econometric practices, in all models the heterogeneity (frailty) issue is addressed at the recipient level rather than at the observation level. We experimented with all three frailty specifications mentioned above, but encountered computation merge problems with discrete frailty models. Thus, only gamma and normal frailty models were estimated. For all three household type groups, the frailty terms are found to be important when estimated with baseline hazards but without any covariates, or with only the post-1997 dummy. But once the full set of covariates as listed in Table 4 is included, the frailty terms become negligible. This is true for all three groups and it makes no difference whether a gamma or normal frailty model is used. If all the groups were now combined and estimated jointly, the frailty term would become significant again. This seems to suggest that there are large heterogeneities across different household types, but little remained at individual levels when one employs a rich set of explanatory variables like those we are using. This finding is quite unexpected. However, since we have estimated the baseline hazards non-parametrically for all models, the effect of frailty misspecifications on coefficients should be small. Table 4 reports the estimate results of complementary log-log discrete-time duration models with gamma frailty for each individual group. The normal frailty complementary log-log models and random effect logit models produce very similar results to those in Table 4 . They have thus been omitted in the interest of brevity. 
Table 4: The complementary log-log gamma frailty model estimates

\begin{tabular}{|c|c|c|c|}
\hline Individual characteristics & Single mother & Single father & $\begin{array}{l}\text { Couple with } \\
\text { children } \\
\text { (Father-headed) }\end{array}$ \\
\hline \multirow[t]{2}{*}{ Post-1997 dummy } & 0.105 & $0.271 * * *$ & $0.183 *$ \\
\hline & $(0.071)$ & $(0.077)$ & $(0.083)$ \\
\hline \multirow[t]{2}{*}{ Immigrant } & $-0.175^{*}$ & $-0.173^{*}$ & $-0.423 * * *$ \\
\hline & $(0.073)$ & $(0.074)$ & $(0.074)$ \\
\hline \multirow[t]{2}{*}{ Age $26-35^{2}$} & $-0.275 * * *$ & $-0.165^{*}$ & 0.245 \\
\hline & $(0.059)$ & $(0.066)$ & $(0.144)$ \\
\hline \multirow[t]{2}{*}{ Age $36-45$} & $-0.471 * * *$ & $-0.246 * *$ & $0.427 * *$ \\
\hline & $(0.077)$ & $(0.080)$ & $(0.148)$ \\
\hline \multirow[t]{2}{*}{ Age $46-55$} & -0.110 & 0.074 & $0.524 * *$ \\
\hline & $(0.111)$ & $(0.126)$ & $(0.168)$ \\
\hline \multirow[t]{2}{*}{ Age $56+$} & $0.547 *$ & 0.410 & $1.189 * * *$ \\
\hline & $(0.256)$ & $(0.333)$ & $(0.332)$ \\
\hline \multirow[t]{2}{*}{ Number of children } & $-0.225^{* * *}$ & $-0.294 * * *$ & $-0.048 *$ \\
\hline & $(0.034)$ & $(0.035)$ & $(0.023)$ \\
\hline \multirow[t]{2}{*}{ Middle school $^{2}$} & -0.306 & 0.132 & 0.010 \\
\hline & $(0.166)$ & $(0.146)$ & $(0.103)$ \\
\hline \multirow[t]{2}{*}{ High school } & -0.068 & 0.240 & 0.144 \\
\hline & $(0.154)$ & $(0.137)$ & $(0.097)$ \\
\hline \multirow[t]{2}{*}{ University } & 0.203 & $0.521 * * *$ & $0.235^{*}$ \\
\hline & $(0.161)$ & $(0.148)$ & $(0.115)$ \\
\hline \multirow[t]{2}{*}{ Postgraduate } & $0.402 *$ & $0.673 * * *$ & $0.427 * * *$ \\
\hline & $(0.176)$ & $(0.184)$ & $(0.127)$ \\
\hline \multirow[t]{2}{*}{ Unemployed $^{2}$} & -0.065 & -0.098 & $-0.226^{* * *}$ \\
\hline & $(0.051)$ & $(0.054)$ & $(0.058)$ \\
\hline \multirow[t]{2}{*}{ Self employed } & 0.326 & -0.270 & $-0.510 * * *$ \\
\hline & $(0.225)$ & $(0.155)$ & $(0.134)$ \\
\hline \multirow[t]{2}{*}{ Non-financial company ${ }^{2}$} & $0.261 * * *$ & $0.278 * * *$ & $0.202 * * *$ \\
\hline & $(0.057)$ & $(0.062)$ & $(0.059)$ \\
\hline \multirow[t]{2}{*}{ Financial company } & $0.341 * *$ & 0.103 & $0.696 * * *$ \\
\hline & $(0.113)$ & $(0.173)$ & $(0.122)$ \\
\hline \multirow[t]{2}{*}{ Other sectors } & $-0.657 * * *$ & -0.071 & -0.042 \\
\hline & $(0.090)$ & $(0.087)$ & $(0.083)$ \\
\hline \multirow[t]{2}{*}{ Social assistance recipient } & $-0.173 *$ & $-0.152 *$ & $-0.453 * * *$ \\
\hline & $(0.076)$ & $(0.071)$ & $(0.101)$ \\
\hline \multirow[t]{2}{*}{ Homeowners } & $0.261 * * *$ & 0.057 & $0.189 * *$ \\
\hline & $(0.062)$ & $(0.065)$ & $(0.060)$ \\
\hline Growth of local unemployment rate, $\%$ & $-0.007 * * *$ & $-0.005 * * *$ & $-0.003 * * *$ \\
\hline
\end{tabular}




\begin{tabular}{|c|c|c|c|}
\hline & $(0.001)$ & $(0.001)$ & $(0.001)$ \\
\hline \multirow[t]{2}{*}{ Growth of local housing sale price, $\%$} & $0.012 *$ & 0.009 & $0.025 * * *$ \\
\hline & $(0.005)$ & $(0.006)$ & $(0.006)$ \\
\hline \multicolumn{4}{|l|}{ Duration Dependence Pattern } \\
\hline \multirow[t]{2}{*}{$1^{\text {st }}$ year spell } & $-1.143^{* * *}$ & $-1.547 * * *$ & $-2.115^{* * *}$ \\
\hline & $(0.183)$ & $(0.177)$ & $(0.205)$ \\
\hline \multirow[t]{2}{*}{$2^{\text {nd }}$ year spell } & $-0.845^{* * *}$ & $-1.217 * * *$ & $-1.706^{* * *}$ \\
\hline & $(0.190)$ & $(0.176)$ & $(0.196)$ \\
\hline \multirow[t]{2}{*}{$3^{\text {rd }}$ year spell } & $-0.907 * * *$ & $-1.317 * * *$ & $-1.636^{* * *}$ \\
\hline & $(0.207)$ & $(0.180)$ & $(0.195)$ \\
\hline \multirow[t]{2}{*}{$4^{\text {th }}$ year spell } & $-1.039 * * *$ & $-1.376^{* * *}$ & $-1.733 * * *$ \\
\hline & $(0.225)$ & $(0.186)$ & $(0.200)$ \\
\hline \multirow[t]{2}{*}{$5^{\text {th }}$ year spell } & $-0.961 * * *$ & $-1.229 * * *$ & $-1.304 * * *$ \\
\hline & $(0.241)$ & $(0.192)$ & $(0.208)$ \\
\hline \multirow[t]{2}{*}{$6^{\text {th }}$ year spell } & $-0.887 * * *$ & $-1.183^{* * *}$ & $-1.058^{* * *}$ \\
\hline & $(0.261)$ & $(0.203)$ & $(0.226)$ \\
\hline \multirow[t]{2}{*}{$7^{\text {th }}$ year spell } & $-1.052 * * *$ & $-1.148 * * *$ & $-1.420^{* * *}$ \\
\hline & $(0.284)$ & $(0.218)$ & $(0.257)$ \\
\hline \multirow[t]{2}{*}{$8^{\text {th }}$ year spell } & $-0.867^{* *}$ & $-1.081 * * *$ & $-1.503^{* * *}$ \\
\hline & $(0.303)$ & $(0.238)$ & $(0.288)$ \\
\hline \multirow[t]{2}{*}{$9^{\text {th }}$ year spell } & $-1.041^{* *}$ & $-1.489^{* * *}$ & $-1.526^{* * *}$ \\
\hline & $(0.330)$ & $(0.306)$ & $(0.320)$ \\
\hline \multirow[t]{2}{*}{$10+$ year spell } & $-0.920 * *$ & $-1.500 * * *$ & $-1.793 * * *$ \\
\hline & $(0.352)$ & $(0.314)$ & $(0.346)$ \\
\hline County dummies & Yes & Yes & Yes \\
\hline \multicolumn{4}{|l|}{ Summary Statistics } \\
\hline \multirow[t]{2}{*}{ Gamma (Sigmau) variance } & .091 & .079 & .053 \\
\hline & $(.104)$ & $(.062)$ & $(.073)$ \\
\hline \multicolumn{4}{|l|}{ LR test of Gamma var $=0$} \\
\hline LR Chi2(df=1) & .800 & 671 & .567 \\
\hline \multicolumn{4}{|c|}{ Test against monotonic baseline hazard ${ }^{4}$} \\
\hline LR Chi2(df=9) & 64.84 & 96.91 & 200.08 \\
\hline Wald Chi2 $(\mathrm{df}=51)^{5}$ & $4646(\mathrm{df}=51)$ & $2247(\mathrm{df}=51)$ & $3144(\mathrm{df}=51)$ \\
\hline Log likelihood $1^{6}$ & -5276.65 & -3201.46 & -4580.59 \\
\hline Log likelihood 2 & -5276.25 & -3201.46 & -4580.30 \\
\hline Number of spell observations & 11087 & 5606 & 8682 \\
\hline \multicolumn{4}{|c|}{$\begin{array}{l}\text { Notes: } 1 .^{*} \mathrm{p}<0.1 ; * * \mathrm{p}<0.05 ; * * * \mathrm{p}<0.01 .2 \text {. Reference for age dummies is below } 25 \text {, } \\
\text { reference for education is primary school and below, reference for labour market status is } \\
\text { employed, reference for industry of employment is public administration sector. } 3 \text {. } \\
\text { Homeowners include cooperative owners. } 4 \text {. Test against log }(\mathrm{t}) \text { specification of baseline } \\
\text { hazards, the critical value of chi-square statistics with } 9 \mathrm{df} \text { at } 0.01 \text { level is } 21.67 .5 \text {. Tests of } \\
\text { joint effects of covariates. } 6 \text {. Log-likelihood } 1 \text { refers to the model without imposing any } \\
\text { frailty and log-likelihood } 2 \text { refers to the frailty model. }\end{array}$} \\
\hline
\end{tabular}




\section{A caveat}

Before starting to examine the estimate results, one should be very cautious of a common pitfall in interpreting results of non-linear binary response regressions. It is often interesting to know whether the covariate effects differ across different groups. However, not every analyst is clearly aware that in the non-linear binary choice regressions direct comparisons of the across-group coefficients are valid only if the residuals across groups are not substantially different (Allison,1999). ${ }^{12}$ Hoetker (2004) developed tests of equal residual variation across groups in non-linear models. Applying the Hoetker tests, we found that the null of equal residual variation between the single mother and single father recipients could not be rejected (the LR statistics is 0.40 and the Wald chi-square test is 0.38 ): thus the estimated covariate coefficients of the two groups are directly comparable. But we found that the null of equal residual variation between the single father and couple with children recipients is strongly rejected (The LR statistics is 26.76 and the Wald chi-square statistics is 15.57). Hence the relative magnitudes of the estimated coefficients between the single father and couple with children recipients are not informative on the differentials of covariate effects between the two groups. This is a pitfall one should keep in mind when reading the estimates.

\section{Duration dependence}

Duration dependence pattern is the key interest in this paper, therefore the discussion of estimation results begins with this issue. According to Table 4 , it is evident that the duration dependence patterns are fairly comparable across the individual groups: all are non-monotonic; the hazards rise after the first year, fall some periods later and rise again. We test the piececonstant specifications of baseline hazards against the monotonic specifications. For all groups, the monotonic specifications are strongly rejected. The test statistics are reported in Table 4.

However, one may also find that the changes in hazards after the first year are rather small, especially for the single groups. One could not reject the null that the hazards between the third year and the tenth year are the same

\footnotetext{
${ }^{12}$ Unlike linear regressions, the coefficients estimated by logit/probit/clogit models are confounded with residual variations, hence the coefficients are not directly comparable if the residual variations are not equal (Allison,1999).
} 
for the single mothers (LR chi-square $(\mathrm{df}=7)=7.95$ and $\mathrm{p}$-value is 0.33 ). We are also unable to reject the null that all the hazards after the first year are the same for the single father group (LR chi-square $(\mathrm{df}=8)=8.34$ and $\mathrm{p}$ value is 0.40 ). For the couple with children group, one could not reject the null that the hazards between the second and fourth year are the same (LR chi-square $(\mathrm{df}=2)=0.70)$ and the null that all the hazards after the seventh year are the same (LR chi-square $(\mathrm{df}=3)=3.69$ and $\mathrm{p}$-value is 0.29 ). Although one may be tempted to group the intervals with seemingly identical hazards into a single interval, we feel it is advantageous to maintain the current number of segments to have more functional flexibility and reduce the impacts of potential frailty misspecification.

To summarise, for any group and in any situation, there is no indication of negative duration dependence. For all groups, the exit hazards rise after the first year and never drop below thereafter. Experimenting with different model specifications and various frailty controls did not change this finding. With these findings, we conclude that there is nothing to indicate that the welfare trap effect should be a serious concern for the Swedish housing allowance system.

How can we explain this finding? We noted the high generosity of the Swedish housing allowance system in Section 2, thus the result of no negative duration dependence seems quite surprising. Someone may attribute it to the $20 \%$ deduction rate in the Swedish housing allowance system, as they feel this ratio is fairly low. Note, however, that a large fraction of Swedish recipients were occupying full-time or part-time jobs. Combined with the notoriously high marginal tax of labour incomes in Sweden and the implicit tax of other means-tested transfers, a deduction rate of $20 \%$ may not be as low as it appears. In addition, Nordvik \& Åhren (2005) examined the housing allowance system in Norway, where the deduction rate is much higher. However, they also failed to find evidence of negative duration dependence, thus the flatness of deduction rate in Sweden does not seem to be the key reason for our finding. We can naturally speculate that public assistances in housing consumption may actually have helped the assisted poor to step out of poverty, as proponents of public housing programs have asserted. But we lack sufficient data, and it is furthermore beyond the scope of this paper, to substantiate this speculation.

More likely, as Murray (1994) demonstrated, the value of in-kind benefits is usually lower than their face monetary value while the non-salary benefits associated with a regular job are often undervalued. These 
problems become more severe when we consider the remaining/exiting choice in a partial analysis framework. Another crucial point is that, in real life, households either occupy full-time/part-time jobs or completely leave jobs, implying that the marginal adjustment of labour supply is not so easily and freely as it is analysed in the theoretic models. For example, it is reported that in 2002 alone, there were about 120,000 eligible households did not apply for the housing allowance available to them (SCB 2004; recited from Dagens Nyheter, 2003). Thus, the assumed disincentives of housing allowance could in fact change very little of a household's behaviour. Gibb (1995) and Stephens (2005) expressed similar opinions in the case of the UK housing benefit.

\section{Effects of individual characteristics}

When investigating the effects of individual characteristics, we find that the three groups share many features, though subtle differences of characteristic's impact across individual groups do exist.

Let us first look at the immigrant status effect. Consistent with typical findings in the welfare literature, immigrants are found to be much less likely to exit once they have entered welfare. This holds true for all three groups. Intuitively, one can attribute this to the relative disadvantage of immigrants in the labour market.

The coefficient of age interval dummy is expected to capture the life-cycle effect. For both single mothers and single fathers, the coefficients of aging are significantly negative except for those aged above 56 years. But for couple with children recipients, the effect of aging is totally reversed: the coefficient is consistently positive.

In the models of welfare duration, the age coefficient must be interpreted with great caution. It may reflect both the potentials of labour market competitiveness and the possibilities of other exit paths correlated with age, for example the chances of exiting from welfare due to marriage. Hence, its examination is more informative when we look at the coefficients of education attainment simultaneously. For single mothers, it is commonly suggested that marriage is an important exit path from welfare (Moffitt, 2000). In our context, one can note that for the single mother recipients, the education attainment coefficients are insignificant except at the postgraduate level, suggesting that labour market competitiveness is not highly decisive for their exit hazards. It thus seems that the negative sign of 
middle-age intervals may more likely reflect their lower chances of exiting from welfare due to marriage compared to very young single females.

In contrast, with the single fathers, one may note that there is evidence of strong effects of education attainment. This suggests that the potential of the labour market competitiveness play dominating roles in males' exit propensities. Therefore, the negative sign of the middle-aged males may point to their lower potential to achieve substantial improvements in future income as opposed to the relatively younger males. The intuition behind this point is that, as one becomes older the variations of the prospective incomes become smaller. However, one may also interpret it as the young males caring more about the negative signal effects of welfare experiences than the middle-aged males do (Moffitt, 1983; Hoynes,2000).

As regards the positive sign of the old-age coefficient for both the single mothers and the single fathers, this may reflect their lower demand for housing allowance as their children grow. It can be also combined with a selection effect: those who have a strong propensity to form a couple have probably done so already, thus the prediction that the exit probability associated with the marriage-related exit path decreases as age increases does not apply to the older singles.

Number of children affects the amount of available housing allowance benefits. As expected, its coefficient is negative and statistically significant for all the three groups.

We now turn to the role of labour market status. We find that the unemployment status at the claim's beginning has negative impacts for all the three groups, but is statistically significant only for the couples and not the singles. One can interpret this as suggesting the singles have more variations in future income than the couples do, thus today's labour market performance is not very informative as regards future development for the singles. This view is partially substantiated when the coefficient significances of the self-employment dummy are compared between singles and couples. However, for the recipients having formal jobs at entry time, their employment sectors are considerably informative regarding their exit hazards, especially for the single mothers and couples.

The coefficient of social assistance recipient status at the spell beginning, however, is significantly negative for all the three groups. This is understandable as it reflects not only the severity of financial difficulties at 
entry time but also indicates one's attitude regarding welfare. The coefficient of homeowner status at the claim's beginning is positive for all groups. One reason that homeowners leave faster than renters do can be due to that the calculation of eligible housing allowance depends on housing expenses rather than on housing costs. For an owner-occupier, housing expenses decrease over time as down payments on loans are paid off. However, this can be also attributed to the homeowners being subject to more stringent regulation in the Swedish housing allowance system. See a discussion of this issue in Chen \& Öst (2005).

\section{Effects of local housing and labour market conditions}

As a key demand factor, the local labour market condition is predicted to play a pivotal role in the welfare transitions. However, previous empirical literature has not consistently substantiated a positive connection between aggregate labour demand and the individual's welfare transition. Hoynes (2000) recently provided a review of literature on this issue. In this paper, besides using county dummies to control other region-specific effects, we enter the local unemployment condition at its annual growth rate rather than its current level. This approach avoids the area self-sorting bias discussed in Hoynes (2000). We also emphasize that it is the over-time variations that matter for individual recipients' exit decisions once they are on welfare.

Estimates reported in Table 4 indicate that deteriorations in the local labour market significantly suppress recipients' exit hazards. Calculated for a representative recipient using the model estimates, it is expected that a $10 \%$ rise in the local unemployment rate will reduce approximately $6 \%$ of exit hazards for single mothers, $4 \%$ for single fathers and $2.5 \%$ for couples with children. ${ }^{13}$ The Swedish housing allowance system appears as an attraction for recipients when economic performance is poor, and is less appealing when the economy performing well. In this sense, Swedish households use the housing allowance as a kind of insurance to counteract temporarily financial difficulties, which is exactly what policymakers expect.

However, it is puzzling to find that the coefficients of growth in local house prices are significantly positive for all three groups. This parameter is expected to reflect the tightness of the local housing market and one would

\footnotetext{
${ }^{13}$ A representative recipient is a native Swedish with one child, aged below 25 , education attainment less than middle school, employed and employed at public administration sector, and resides in Stockholm County. The local housing market and labour market conditions are set at levels of population-average
} 
expect that the more expensive the local housing is, the more a household would need government assistance to alleviate its accommodation burdens. However, the finding reported in Table 4 contradicts this prediction. When the growth of local house sale price is interacted with the homeowner dummy, we found that its effect on homeowners is significantly larger than on renters (not reported here), although its effect on the renters is still statistically significant and positive for all groups.

A likely reason for these findings may be that the growth of local house price is not a proper measure of local housing market tightness, especially when the majority of Swedish recipients are renters. ${ }^{14}$ When we use the growth in local rents instead of the growth in local house sale prices, however, the positive signs remain-- although now not significant at $10 \%$ level for all groups (not reported here). On the other hand, it is reasonable to suspect that local housing market conditions tend to be closely correlated with the local labour market conditions, and the rises in the local house prices/rents reflect certain unmeasured increasing trends in the local economy. Thus, improvements of local labour market increase the house prices while simultaneously suppressing the need for housing allowance. This may be a major reason to explain the positive sign of local housing price/rent growth we found here.

Note that we include county dummies to control for unmeasured regional effects on the exit hazards. Dropping county dummies does not affect the sign and statistical significance of the two coefficients. The point estimate of local market variable coefficient will be slightly larger. The findings above carry through when we replace the local unemployment rates with the indicators of national economy, using either national GDP growth rates or the national unemployment rates. Meanwhile, the coefficients of household characteristics as well as local housing market indicators are little affected by this change.

\section{Effect of 1997 reform}

The coefficients of the post-1997 dummy in the Table 4 are the BA (before and after) estimators and indicate the location differentials in the exit hazards before and after 1997 for each group. We can see that all three

\footnotetext{
${ }^{14}$ The use of rents has its own problem, however. The rental market in Sweden is strictly regulated and thus the over-time variations of rents are not only small but also lagging far behind market conditions.
} 
groups experienced a sizable increase in their exit hazards after 1997. However, we are very aware that the BA estimator can be dubious due to its contamination with the unmeasured trend effects. To overcome this weakness, Chen (2005) exploits the quasi-experimental feature of the 1997 reform and estimated the impacts of this reform on the couple with children recipients using the DD (difference-in-difference) strategy. Interested readers can find more discussions on the reform effects in that paper.

\section{The concluding remarks}

Housing allowances have become increasingly important in the developed countries. Despite their growing popularity in recent decades, they also face increasing controversy (Turner \& Elsinga, 2005). One key concern centres on whether the housing allowance system creates dependence on welfare benefits among its recipients. To answer this question, this paper examines the dynamics of Swedish housing allowance claims between 1991 and 2002. The estimation results of this paper suggest that there is no indication of negative duration dependence existing within the Swedish housing allowance spells. The hazards of dropping out of the system are quite stable after the first year. This finding is consistent across different model specifications and various controls of the heterogeneity issue. We hence conclude that a recipient's exit rates from the system do not decrease over the history of the claim and that the welfare trap effect should not be seen as a serious threat to the Swedish housing allowance system. Possible explanations for this finding are discussed and compared.

The empirical analysis practices in this paper reveal substantial heterogeneities among the recipients. However, it seems that a large fraction of these heterogeneities lie across household types rather than at individual levels, and that separate sub-sample analysis can control for the heterogeneity effect to a satisfying extent. This study indicates that a recipient's demographic characteristics, educational background, and labour market status play important roles in determining claim duration. It is also found that economic contextual conditions are crucial to the exit hazards of recipients. In summary, this paper suggests that recipients are affected more by their perspectives on future income developments than their current financial situation when considering their exit decisions. These findings carry useful implications for policy reconfiguration. 


\section{Appendix}

\section{A.1: Data description}

Table A.1: Sample Spell distribution by duration length and by year

\begin{tabular}{|c|c|c|c|c|c|c|c|c|}
\hline \multirow{3}{*}{$\begin{array}{l}\begin{array}{l}\text { Lenth } \\
\text { (Years) }\end{array} \\
\text { Year } \\
1\end{array}$} & \multicolumn{2}{|l|}{ All } & \multicolumn{2}{|c|}{ Single mother } & \multicolumn{2}{|c|}{ Single father } & \multicolumn{2}{|c|}{$\begin{array}{l}\text { Couple with } \\
\text { children }\end{array}$} \\
\hline & Freq. & Percent & Freq. & Percent & Freq. & Percent & Freq. & Percent \\
\hline & 11,515 & 24.01 & 2,974 & 22.40 & 2,131 & 29.70 & 6,410 & 23.30 \\
\hline 2 & 9,478 & 19.76 & 2,472 & 18.62 & 1,638 & 22.83 & 5,368 & 19.51 \\
\hline 3 & 7,414 & 15.46 & 1,933 & 14.56 & 1,124 & 15.66 & 4,357 & 15.83 \\
\hline 4 & 5,691 & 11.86 & 1,518 & 11.43 & 788 & 10.98 & 3,385 & 12.30 \\
\hline 5 & 4,347 & 9.06 & 1,211 & 9.12 & 560 & 7.80 & 2,576 & 9.36 \\
\hline 6 & 3,133 & 6.53 & 940 & 7.08 & 372 & 5.18 & 1,821 & 6.62 \\
\hline 7 & 2,202 & 4.59 & 727 & 5.48 & 242 & 3.37 & 1,233 & 4.48 \\
\hline 8 & 1,588 & 3.31 & 549 & 4.13 & 143 & 1.99 & 896 & 3.26 \\
\hline 9 & 1,131 & 2.36 & 412 & 3.10 & 85 & 1.18 & 634 & 2.30 \\
\hline 10 & 801 & 1.67 & 299 & 2.25 & 52 & 0.72 & 450 & 1.64 \\
\hline 11 & 497 & 1.04 & 189 & 1.42 & 29 & 0.40 & 279 & 1.01 \\
\hline 12 & 172 & 0.36 & 54 & 0.41 & 12 & 0.17 & 106 & 0.39 \\
\hline Total & 47,969 & 100.00 & 13,278 & 100.00 & 7,176 & 100.00 & 27,515 & 100.00 \\
\hline Mean & 3.78 & & 3.89 & & 3.21 & & 3.75 & \\
\hline$(\mathrm{sd})^{2}$ & $(2.42)$ & & $(2.60)$ & & $(2.14)$ & & $(2.29)$ & \\
\hline Year & Freq. & Percent & Freq. & Percent & Freq. & Percent & Freq. & Percent \\
\hline 1991 & 2,693 & 5.61 & 537 & 4.04 & 325 & 4.53 & 1,831 & 6.65 \\
\hline 1992 & 4,122 & 8.59 & 1,014 & 7.64 & 487 & 6.79 & 2,621 & 9.53 \\
\hline 1993 & 5,265 & 10.98 & 1,292 & 9.73 & 703 & 9.80 & 3,270 & 11.88 \\
\hline 1994 & 7,224 & 15.06 & 1,896 & 14.28 & 1,310 & 18.26 & 4,018 & 14.60 \\
\hline 1995 & 7,027 & 14.65 & 1,698 & 12.79 & 1,206 & 16.81 & 4,123 & 14.98 \\
\hline 1996 & 6,447 & 13.44 & 1,694 & 12.76 & 1,098 & 15.30 & 3,655 & 13.28 \\
\hline 1997 & 3,722 & 7.76 & 1,146 & 8.63 & 617 & 8.60 & 1,959 & 7.12 \\
\hline 1998 & 3,190 & 6.65 & 1,056 & 7.95 & 479 & 6.68 & 1,655 & 6.01 \\
\hline 1999 & 2,651 & 5.53 & 900 & 6.78 & 358 & 4.99 & 1,393 & 5.06 \\
\hline 2000 & 2,170 & 4.52 & 775 & 5.84 & 257 & 3.58 & 1,138 & 4.14 \\
\hline 2001 & 1,827 & 3.81 & 674 & 5.08 & 179 & 2.49 & 974 & 3.54 \\
\hline 2002 & 1,631 & 3.40 & 596 & 4.49 & 157 & 2.19 & 878 & 3.19 \\
\hline Total & 47,969 & 100.00 & 13,278 & 100.00 & 7,176 & 100.00 & 27,515 & 100.00 \\
\hline
\end{tabular}

Notes: 1. Spells here include female-headed couples. Spell and year distributions between male-headed and female-headed couples are rather close. The Likelihood-ratio test statistic 
of homogeneity within couples is: $\chi^{2}(\mathrm{df}=1)=3.5878906$ and $\mathrm{p}=0.058 .2$. Mean spell lengths here are calculated only on the uncensored spells.

Table A.2: Summary statistics of sample recipients

\begin{tabular}{|c|c|c|c|c|}
\hline & Whole $^{1}$ & Single mother & Single father & $\begin{array}{l}\text { Couple } \\
\text { (father-headed) }\end{array}$ \\
\hline Variable & Mean (std) & Mean (std) & Mean (std) & Mean (std) \\
\hline \multicolumn{5}{|c|}{ Characteristics at spell } \\
\hline \multicolumn{5}{|l|}{$\underline{\text { start }}$} \\
\hline Age & $33.77(8.27)$ & $31.47(8.42)$ & $32.13(8.17)$ & $37.18(7.02)$ \\
\hline Age below 25 & 0.18 & 0.28 & 0.24 & 0.03 \\
\hline Age $26-35$ & 0.44 & 0.45 & 0.46 & 0.43 \\
\hline Age $36-45$ & 0.28 & 0.19 & 0.22 & 0.42 \\
\hline Age $46-55$ & 0.09 & 0.07 & 0.07 & 0.11 \\
\hline Age 56 above & 0.01 & 0.01 & 0.01 & 0.01 \\
\hline Immigrant & 0.18 & 0.15 & 0.17 & 0.21 \\
\hline No. Of children & $1.24(1.24)$ & $1.08(1.08)$ & $1.16(0.54)$ & $2.18(1.06)$ \\
\hline \multicolumn{5}{|l|}{ Education } \\
\hline Primary school & 0.06 & 0.03 & 0.05 & 0.09 \\
\hline Middle school & 0.18 & 0.16 & 0.19 & 0.19 \\
\hline High school & 0.55 & 0.58 & 0.56 & 0.52 \\
\hline University & 0.14 & 0.17 & 0.16 & 0.12 \\
\hline Postgraduate & 0.06 & 0.06 & 0.04 & 0.08 \\
\hline Housing allowanc & $6.87(7.01)$ & $8.27(8.28)$ & $5.12(4.87)$ & $5.62(4.90)$ \\
\hline \multicolumn{5}{|c|}{$1000 \mathrm{SEK} /$ Year } \\
\hline $\begin{array}{l}\text { Homeowners an } \\
\text { cooperatives }\end{array}$ & \multicolumn{3}{|c|}{ cooperatives } & 0.54 \\
\hline Self-employed, & 0.05 & 0.02 & 0.06 & 0.08 \\
\hline $\begin{array}{l}\text { Social assistan } \\
\text { receipt, }\end{array}$ & 0.16 & 0.16 & 0.22 & 0.09 \\
\hline Unemployed, & 0.26 & 0.26 & 0.35 & 0.18 \\
\hline \multicolumn{5}{|l|}{ Employment Sector } \\
\hline Public administration, & 0.31 & 0.44 & 0.25 & 0.23 \\
\hline $\begin{array}{l}\text { Non-finance compan } \\
\%\end{array}$ & 0.46 & 0.35 & 0.58 & 0.49 \\
\hline Finance company, $\%$ & 0.11 & 0.13 & 0.05 & 0.12 \\
\hline Other sector; \% & 0.12 & 0.07 & 0.12 & 0.16 \\
\hline \multicolumn{5}{|l|}{ Time-varying variables } \\
\hline $\begin{array}{l}\text { Local housing sa } \\
\text { price, } 1000 \mathrm{SEK} / \mathrm{sq}\end{array}$ & $5.98(1.93)$ & $6.01(1.97)$ & $5.85(1.80)$ & $5.94(1.84)$ \\
\hline Local unemployme & t $6.33(2.38)$ & $6.52(2.33)$ & $6.89(2.24)$ & $5.79(2.42)$ \\
\hline
\end{tabular}


rate, $\%$

Growth of local housing 1.15(0.84)

$0.77(0.82)$

$1.10(0.76)$

$1.51(0.91)$

price, $\%$

Growth of local39.99(45.8)

$38.37(46.14)$

$30.03(42.0)$

$49.68(45.31)$

unemployment rate, $\%$

2974

2131

2813

households

Number

of 31745

13278

7176

11291

observations (Spell-

years)

Spells after 1997

$35.17 \%$

$38.76 \%$

$28.53 \%$

$22.14 \%$

Notes: 1. Include only singles and male-headed couples;

2 . Incomes and prices are constant at 2002 level using deflation of CPI (Consumer Price Index).

3. Country-level panel of local sale price information provided by IBF and countylevel panel of local unemployment rate information obtained from the website of SCB. 


\section{A2. Fitted survivals and hazards}

Figure A1: The fitted survival rates for a representative recipient

Fitted Survivals by family type, 1991-2002

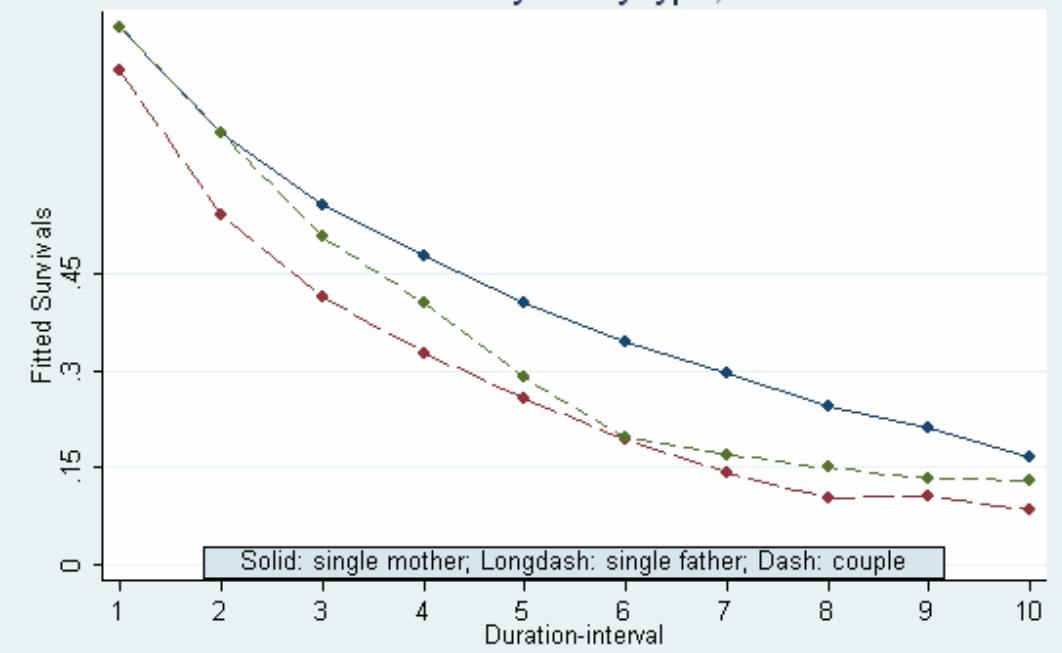

Figure A2: The fitted hazards for a representative recipient

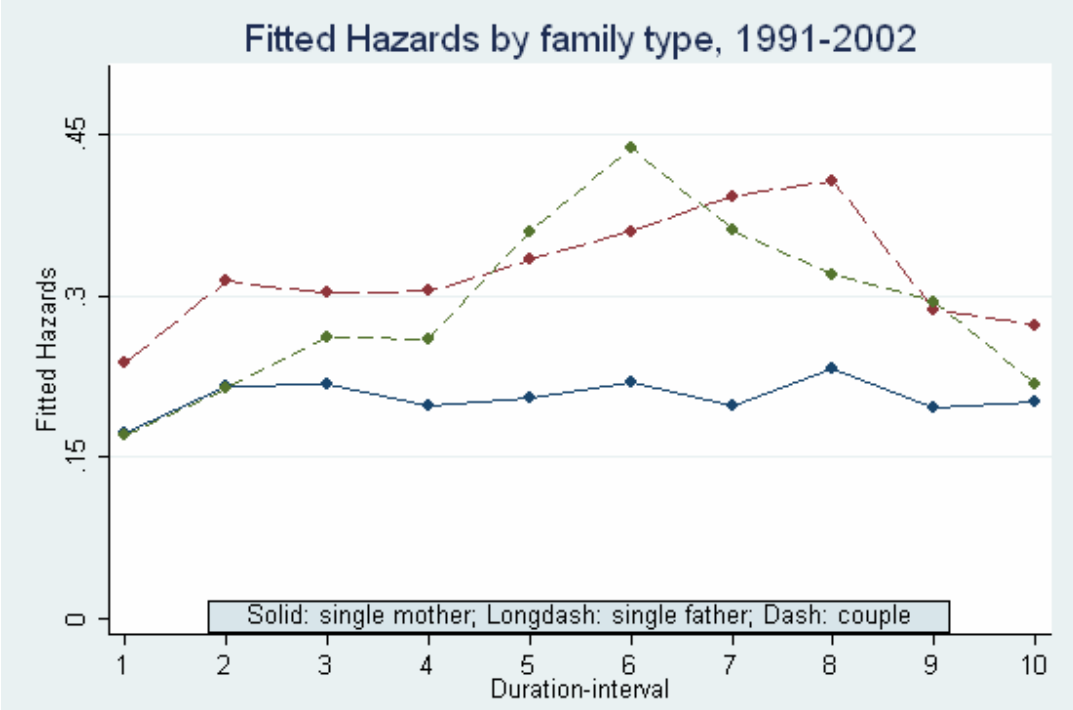

Notes: The estimates of complementary log-log hazard models are used. The representative recipient is Swedish, with one child, aged below 25, education attainment lower than middle school, employed and employed at public administration sector, and resides in Stockholm county. Local housing market and labour market conditions are set at the average levels of spell population. 


\section{References}

Allison, P. D. (1999): "Comparing Logit and Probit Coefficients across Groups." Sociological Methods \& Research, 28:2, pp.186-208.

Behrendt, C. (2000): "Do Means-Tested Benefits Alleviate Poverty? Evidence on Germany, Sweden and the United Kingdom from the Luxembourg Income Study." Journal of European Social Policy, 10:1, pp.23-41.

Bhat, C. R. (1996): "A Hazard-Based Duration Model of Shopping Activity with Nonparametric Baseline Specification and Nonparametric Control for Unobserved Heterogeneity." Transportation Research Part B: Methodological, 30:3, pp.189-207.

Boverket (1999): "Housing Allowances During the Nineteen Nineties (Bostadsbidraget under 90-Talet) (in Swedish)." The Swedish National Housing Board (Boverket): Karlskrona.

Chen, J. (2005): "Housing Allowance Benefits and the Duration of Recipient Spells: Lessons from a Reform in Sweden." Chapter 3 in Chen, J. (2005) "Empirical Essays on Housing Allowance, Housing Wealth and Aggregate Consumption". PhD dissertation, Economic Studies 91, Department of Economics, Uppsala University.

Chen, J. and Öst, C. E. (2005): "Housing Allowance and the Recipient's Homeownership: Evidence from a Panel Data Study in Sweden." Housing Studies, 20:4, pp.605-25.

Cox, D.R. (1972): "Regression Models and Life-Cycles (with Discussions)." Journal of Royal Statistic Society B, 34, pp.187-220.

DagensNyheter (2003): "120.000 Missar Bidrag." Dagens Nyheter, Stockholm. June 27, 2003

Ditch, J., Lewis, A., and Wilcox, S. (2001): "Social Housing, Tenure and Housing Allowance: An International Review." York University: York, UK.

Early, D. W. (2004): "The Determinants of Homelessness and the Targeting of Housing Assistance." Journal of Urban Economics, 55:1, pp.195-214.

Edin, P-A. and Fredriksson, P. (2000): "Linda-Longitudinal Individual Data for Sweden." Working Paper 2000:25, Department of Economics, Uppsala University.

Edin, P-A. and Gustavsson, M. (2004): "Time out of Work and Skill Depreciation." Working Paper 2004:14, Department of Economics, Uppsala University.

Fallis, G. (1990): "The Optimal Design of Housing Allowances." Journal of Urban Economics, 27:3, pp.381-97.

Fallis, G. (1993): "On Choosing Social-Policy Instruments - the Case of Nonprofit Housing, Housing Allowances or Income Assistance." Progress in Planning, 40:1, pp.188 .

Fallis, G., Hosios, A. J., and Jump, G. V. (1995): "Housing Allowances, Nonprofit Housing, and Cost-Effective Program Choice." Journal of Housing Economics, 4:2, pp.136-52. 
Fischer, W. (2000): "Labor Supply Effects of Federal Rental Subsidies." Journal of Housing Economics, 9:3, pp.150-74.

Gibb, K. (1995): "A Housing Allowance for the UK - Preconditions for an IncomeRelated Housing Subsidy." Housing Studies, 10:4, pp.517-32.

Han, A. and Hausman, J. A. (1990): "Flexible Parametric-Estimation of Duration and Competing Risk Models." Journal of Applied Econometrics, 5:1, pp.1-28.

Heckman, J. and Singer, B. (1984): "A Method for Minimizing the Impact of Distributional Assumptions in Econometric Models for Duration Data." Econometrica, 52:2, pp.271-320.

Hoetker, G. (2004): "Confounded Coefficients: Accurately Comparing Logit and Probit Coefficients across Groups." Manuscript, College of Business, University of Illinois at Urbana Champaign.

Hoynes, H. W. (2000): "Local Labor Markets and Welfare Spells: Do Demand Conditions Matter?" Review of Economics and Statistics, 82:3, pp.351-68.

Hungerford, T. L. (1996): "The Dynamics of Housing Assistance Spells." Journal of Urban Economics, 39:2, pp.193-208.

Katz, L. F., Kling, J. R., and Liebman, J. B. (2001): "Moving to Opportunity in Boston: Early Results of a Randomized Mobility Experiment." Quarterly Journal of Economics, 116:2, pp.607-54.

Kemp, P. A. (2000): "The Role and Design of Income-Related Housing Allowance." International Social Security Review, 53, pp.43-57.

Koning, R. H. and Ridder, G. (1997): "Rent Assistance and Housing Demand." Journal of Public Economics, 66:1, pp.1-31.

Laferrere, A. and Le Blanc, D. (2004): "How Do Housing Allowances Affect Rents? An Empirical Analysis of the French Case." Journal of Housing Economics, 13:1, pp.36-67.

Lancaster, Tony. (1979): "Econometric Methods for the Duration of Unemployment." Econometrica, 47:4, pp.939-56.

le Blanc, D. and Laferrere, A. (2001): "The Effect of Public Social Housing on Households' Consumption in France." Journal of Housing Economics, 10:4, pp.429-55.

Leonesio, M. V. (1988): "In-Kind Transfers and Work Incentives." Journal of Labor Economics, 6:4, pp.515-29.

Ludwig, J., Duncan, G. J., and Pinkston, J. C. (2004): "Housing Mobility Programs and Economic Self-Sufficiency: Evidence from a Randomized Experiment." Journal of Public Economics, 89:1, pp.131-56.

Meyer, B. D. (1990): "Unemployment-Insurance and Unemployment Spells." Econometrica, 58:4, pp.757-82.

Moffitt, R. (1983): "An Economic Model of Welfare Stigma." American Economic Review, 73:5, pp.1023-35.

Moffitt, R. (1992): "Incentive Effects of the United-States Welfare System - a Review." Journal of Economic Literature, 30:1, pp.1-61.

Moffitt, R. (2000): "Welfare Benefits and Female Headship in Us Time Series." American Economic Review, 90:2, pp.373-77.

MOS. (2004): "Housing and Housing Policy in Sweden." Fact Sheet from Swedish Ministry of Sustainable Development: Stockholm. 
Munro, A. (1989): "In-Kind Transfers, Cash Grants and the Supply of Labor." European Economic Review, 33:8, pp.1597-604.

Murray, M. P. (1980): "A Reinterpretation of the Traditional Income-Leisure Model, with Application to in-Kind Subsidy Program." Journal of Public Economics, 14, pp.69-81.

Murray, M. P. (1994): "How Inefficient Are Multiple in-Kind Transfers." Economic Inquiry, 32:2, pp.209-27.

Newman, S. J. and Harkness, J. M. (2002): "The Long-Term Effects of Public Housing on Self-Sufficiency." Journal of Policy Analysis and Management, 21:1, pp.21-43.

Nordvik, V. and Åhren, P. (2005): "The Duration of Housing Allowance Claims and Labour Market Disincentives: The Norwegian Case." European Journal of Housing Policy, 5:2, pp.131-46.

Painter, G. (2001): "Low-Income Housing Assistance: Its Impact on Labour Force and Housing Program Participation." Journal of Housing Research, 12:1, pp.1-26.

Plant, M. W. (1984): "An Empirical Analysis of Welfare Dependence." American Economic Review, 74:4, pp.673-84.

Prentice, R.L. and Gloeckler, L.A. (1978): "Regression Analysis of Grouped Survival Data with Application to Breast Cancer Data." Biomertrics, 34:1, pp.57-67.

Priemus, H. and Kemp, P. (2004): "The Present and Future of Income-Related Housing Support: Debates in Britain and the Netherlands." Housing Studies, 19:4, pp.653-68.

RFV (2003): "Social Insurance in Sweden 2003: Family Assets--Time and Money." The National Social Insurance Board of Sweden.

RFV (2005): "The Scope and Financing of Social Insurance in Sweden 2002-2005." The National Social Insurance Board of Sweden.

Rosenbaum, E. and Harris, L. E. (2001): "Residential Mobility and Opportunities: Early Impacts of the Moving to Opportunity Demonstration Program in Chicago." Housing Policy Debate, 12:2, pp.321-46.

SCB (2002): Survey of Housing and Rents 2002: Statistics Sweden.

SCB (2004): Bostads Och Byggnadsstatistisk Årsbok 2004 (Yearbook of Housing and Building Statistics 2004): Statistics Sweden.

SCB (2005): Statistical Yearbook of Sweden 2005: Statistics Sweden.

Schone, B. S. (1992): "Do Means Tested Transfers Reduce Labor Supply." Economics Letters, 40:3, pp.353-57.

Shroder, M. (2002): "Does Housing Assistance Perversely Affect Self-Sufficiency? A Review Essay." Journal of Housing Economics, 11:4, pp.381-417.

Singer, J. D. and Willett, J. B. (2003): Applied Longitudinal Data Analysis: Modelling Change and Event Occurrence. Oxford ; New York: Oxford University Press.

Stephens, M. (2005): "An Assessment of the British Housing Benefit System." European Journal of Housing Policy, 5:2, pp.111-29.

Susin, S. (2002): "Rent Vouchers and the Price of Low-Income Housing." Journal of Public Economics, 83:1, pp.109-52.

Turner, B. and Whitehead, C. M. E. (2002): "Reducing Housing Subsidy: Swedish Housing Policy in an International Context." Urban Studies, 39:2, pp.201-17. 
Turner, B. and Elsinga, M. (2005): "Housing Allowance: Finding a Balance between Social Justice and Market Incentives." European Journal of Housing Policy, 5:2, pp.10309.

Turner, M. A. (1998): "Moving out of Poverty: Expanding Mobility and Choice through Tenant-Based Housing Assistance." Housing Policy Debate, 9:2, pp.373-94.

Åhren, P. (2004): "Housing Allowance," in Housing and Housing Policy in the Nordic Countries. Lujanen, M. (ed.). Copenhagen: Nordic Council of Ministers. 
WORKING PAPERS*

Editor: Nils Gottfries

2004:16 Iida Häkkinen, Do University Entrance Exams Predict Academic Achievement? 38 pp.

2004:17 Mikael Carlsson, Investment and Uncertainty: A Theory-Based Empirical Approach. 27 pp.

2004:18 N. Anders Klevmarken, Towards an Applicable True Cost-of-Living Index that Incorporates Housing. 8 pp.

2004:19 Matz Dahlberg and Karin Edmark, Is there a "Race-to-the-Bottom" in the Setting of Welfare Benefit Levels? Evidence from a Policy Intervention. $34 \mathrm{pp}$.

2004:20 Pär Holmberg, Unique Supply Function Equilibrium with Capacity Constraints. $31 \mathrm{pp}$.

2005:1 Mikael Bengtsson, Niclas Berggren and Henrik Jordahl, Trust and Growth in the 1990s - A Robustness Analysis. 30 pp.

2005:2 Niclas Berggren and Henrik Jordahl, Free to Trust? Economic Freedom and Social Capital. 31 pp.

2005:3 Matz Dahlberg and Eva Mörk, Public Employment and the Double Role of Bureaucrats. 26 pp.

2005:4 Matz Dahlberg and Douglas Lundin, Antidepressants and the Suicide Rate: Is There Really a Connection? $31 \mathrm{pp}$.

2005:5 Maria Vredin Johansson, Tobias Heldt and Per Johansson, Latent Variables in a Travel Mode Choice Model: Attitudinal and Behavioural Indicator Variables. $31 \mathrm{pp}$.

2005:6 Katarina Nordblom and Henry Ohlsson, Tax Avoidance and Intra-Family Transfers. 25 pp.

2005:7 Sören Blomquist and Luca Micheletto, Optimal Redistributive Taxation when Government’s and Agents’ Preferences Differ. 22 pp.

2005:8 Ruth-Aïda Nahum, Income Inequality and Growth: A Panel Study of Swedish Counties 1960-2000. 39 pp.

2005:9 Olof Åslund and Peter Fredriksson, Ethnic Enclaves and Welfare Cultures Quasi-experimental Evidence. 37 pp.

2005:10 Annika Alexius and Erik Post, Exchange Rates and Asymmetric Shocks in Small Open Economies. 31 pp.

\footnotetext{
* A list of papers in this series from earlier years will be sent on request by the department.
} 
2005:11 Martin Ågren, Myopic Loss Aversion, the Equity Premium Puzzle, and GARCH. 34 pp.

2005:12 Pär Holmberg, Numerical Calculation of an Asymmetric Supply Function Equilibrium with Capacity Constraints. 18 pp.

2005:13 Jovan Zamac, Winners and Losers from a Demographic Shock under Different Intergenerational Transfer Schemes. 44 pp.

2005:14 Peter Welz and Pär Österholm, Interest Rate Smoothing versus Serially Correlated Errors in Taylor Rules: Testing the Tests. 29 pp.

2005:15 Helge Bennmarker, Kenneth Carling and Bertil Holmlund, Do Benefit Hikes Damage Job Finding? Evidence from Swedish Unemployment Insurance Reforms. 37 pp.

2005:16 Pär Holmberg, Asymmetric Supply Function Equilibrium with Constant Marginal Costs. 27 pp.

2005:17 Pär Holmberg, Comparing Supply Function Equilibria of Pay-as-Bid and Uniform-Price Auctions. 25 pp.

2005:18 Anders Forslund, Nils Gottfries and Andreas Westermark, Real and Nominal Wage Adjustment in Open Economies. 49 pp.

2005:19 Lennart Berg and Tommy Berger, The Q Theory and the Swedish Housing Market - An Empirical Test. 16 pp.

2005:20 Matz Dahlberg and Magnus Gustavsson, Inequality and Crime: Separating the Effects of Permanent and Transitory Income. 27 pp.

2005:21 Jenny Nykvist, Entrepreneurship and Liquidity Constraints: Evidence from Sweden. 29 pp.

2005:22 Per Engström och Bertil Holmlund, Jenny Nykvist, Worker Absenteeism in Search Equilibrium. 35pp.

2005:23 Peter Hästö och Pär Holmberg, Some inequalities related to the analysis of electricity auctions. 7pp.

2006:1 Jie Chen, The Dynamics of Housing Allowance Claims in Sweden: A discrete-time hazard analysis. 37pp.

See also working papers published by the Office of Labour Market Policy Evaluation http://www.ifau.se/

ISSN 0284-2904 